\title{
CANADA, U.K. STAND SHOULDER TO SHOULDER AMID GLOBAL TURMOIL*
}

\section{Zak Biggs}

The current era of global uncertainty has strained the relationships of many formerly reliable partners. Although the Canada-U.K. relationship has been the exception, both countries are going through rough patches with other major partners - targeted by American tariffs, Canada was forced to play defence during aggressive NAFTA renegotiations. The United Kingdom is attempting to divorce its largest trading partner, the European Union. These issues have fostered conditions for the U.K. and Canada to become even stronger partners. Now is the time for our countries to capitalize on our longstanding relationship while also looking outwards for new opportunities.

\footnotetext{
* This research was financially supported by the Government of Canada via a partnership with Western Economic Diversification.
} 


\section{LE CANADA ET LE ROYAUME-UNI SE SOUTIENNENT MUTUELLEMENT EN PLEIN CFUR DE LA TOURMENTE MONDIALE*}

\section{Zak Biggs}

L'époque actuelle d'incertitude mondiale a mis à rude épreuve les relations de nombreux partenaires autrefois fiables. Bien que la relation entre le Canada et le Royaume-Uni ait fait figure d'exception, les deux pays traversent des périodes difficiles avec d'autres partenaires importants : ciblé par les tarifs américains, le Canada a été contraint de se mettre sur la défensive lors des renégociations agressives de l'ALENA. Le R. U., quant à lui, tente de divorcer de son principal partenaire commercial, l'Union européenne. Ces enjeux favorisent les conditions pour que le Royaume-Uni et le Canada deviennent des partenaires encore plus forts. Le moment est venu pour ces pays de capitaliser sur leurs relations de longue date tout en recherchant de nouvelles occasions à l'étranger.

\footnotetext{
* Cette recherche a été soutenue financièrement en partie par le gouvernement du Canada via Diversification de l'économie de l'Ouest Canada.
} 


\section{NEW REALITIES MEAN GREATER NEED FOR COLLABORATION}

The stage was set when Prime Minister Theresa May visited Prime Minister Justin Trudeau in September 2017. This visit saw the launch of new initiatives including the $3+3$ Dialogue, designed to facilitate closer collaboration between our ministers of foreign affairs, defence and development assistance. Also established were partnerships on innovation collaboration, defence and security, clean growth, digital government services and gender equality. This is a moment of great opportunity for Canada-U.K. collaboration, and that was the message at a recent conference entitled Shoulder to Shoulder: Forging a New Canada-UK Relationship. The conference took place over two days at Goodenough College in central London and also featured a reception at the Canadian High Commission in Trafalgar Square.

"Brexit has undoubtedly raised the importance of our relationship with Canada," Caroline Saunders, the British consul general to Alberta, Saskatchewan and Manitoba, declared at the conference, where discussants fleshed out practical policy routes for improving our countries' positions in the global economy, enhancing our security and increasing our influence in the international arena. Led by the School of Public Policy at the University of Calgary, with the support of the university's Faculty of Law and the British ConsulateGeneral in Calgary, the conference was timely and wide-ranging. Focused and frank discussion took place over two days among participants from academia, business, government and the military.

\section{TRADE AND INVESTMENT AN ESSENTIAL PART OF OUR RELATIONSHIP}

Trade and investment is one area where these two countries have long had a strong relationship. CETA, the free trade agreement between Canada and the EU, entered into force last year and eased market access and labour mobility. The U.K. is Canada's biggest market within the EU. Brexit, however, will see the U.K. leave the EU and CETA. Andrew Percy, U.K. MP and trade envoy to Canada, stated at the Shoulder to Shoulder conference that "in order to have a seamless transition to our trading relationship, and avoid any unnecessary disruption, the U.K. and Canada are working on a bilateral trade agreement." He emphasized that "this is one of the U.K.'s top priorities post-Brexit."

Speakers discussed ways to strengthen our economic relations by addressing trade irritants. These included improvements to labour mobility, the mutual recognition of professional certifications and reducing internal barriers to trade within Canada. The latter was the focus of political efforts by Canadian premiers and Trudeau in 2018, although they accomplished little. Participants spoke about their frustration that it is easier for some Canadian producers to sell to the U.K. than to neighbouring provinces. This harms Canadian productivity and competitiveness and should remain a top priority for policy-makers.

Rising public skepticism of trade and the best policy responses also came up for discussion. Speakers acknowledged the need to ensure that society broadly shares the prosperity and productivity dividends of trade and globalization. Policy options for this include targeted benefits to negatively affected workers, redistributive tax policies, retraining programs and 
educational reform. All these approaches, however, have serious faults and their efficacy is context-specific. It was thus stated that perhaps the best approach is a strong social safety net that will protect those on the losing end of trade and globalization.

\section{AN OPPORTUNITY TO INTEGRATE OUR FINANCIAL MARKETS}

The inflection point at which we stand also presents an opportunity to integrate Canadian and U.K. financial markets. Brexit, American uncertainty and a recent Supreme Court of Canada decision on the regulation of capital markets have opened a window of opportunity for mutually beneficial changes. The Shoulder to Shoulder conference saw the formation of a coalition of stakeholders driven to seize this opportunity. "We see huge potential benefit in an integrated Canada-U.K. financial market and have begun working with stakeholders such as regulators, banks, issuers, investors and academic institutions to form a coherent vision and make this happen," said Prof. Bryce Tingle, N. Murray Edwards Chair in Business Law at the University of Calgary.

\section{DEFENDING OURSELVES AND THE LIBERAL INTERNATIONAL ORDER}

Standing together on defence and security is also critical for Canada and the U.K. in these uncertain times. The U.S. withdrawal from global leadership and China's step forward have placed more onus on Canada and the U.K. to defend the liberal international order. "While the rise of China is certainly a factor, both countries are squarely focused on Russia," explained Prof. Elinor Sloan at the Shoulder to Shoulder conference. This increases the need for Canada and the U.K. to work together to counter hybrid warfare threats and act as champions of democracy and open markets.

Canada and the U.K. have stepped up to defend these values. Both are training Ukrainian security forces and are members of the European Centre of Excellence for Countering Hybrid Threats, which NATO and the EU established in 2017. Further opportunities to collaborate include sharing learning on offensive cyber-operations, which the Canadian Forces has only recently adopted. "This is an area that naturally lends itself to enhanced bilateral co-operation, since NATO does not currently engage in offensive cyberoperations," added Sloan. Countering cyber-threats is crucial given that Russia may target Canada's 2019 federal election to sow social discord, as seen in the U.S., Germany and U.K.

The two countries are also defending the liberal international order by seeking to strengthen multilateral international organizations. Their effort toward World Trade Organization (WTO) reform is a prime example. Canada and the U.K. were among a group of countries that recently met in Ottawa to find ways to improve the multilateral trading system by strengthening and modernizing the WTO.

While global disruption has harmed relations between many countries, it has only raised the importance of the Canada-U.K. relationship. Our countries have responded to disruption by standing shoulder to shoulder in defending ourselves and the rules-based international system. We are working together to counter Russian aggression in Ukraine 
and cyber-space. Furthermore, we are working to capitalize on the strong partnerships we have in trade, investment and financial markets. This is illustrated by efforts to integrate our financial markets and the expected signing of a Canada-U.K. trade agreement in 2019.

\section{A FOUNDATION FOR FUTURE COLLABORATION}

Global turmoil has increased the need for Canada and the UK to build on our shared values and work together to champion free trade, collective security and multilateralism. The recent Shoulder to Shoulder conference has built a foundation on which our researchers, policymakers and business leaders can meet and share insights into these global challenges. Canada's High Commissioner in the UK, Janice Charette, stressed that the discussions come at a pivotal time when shared values are being challenged. "We need great minds engaging in discussions like we've had at this conference, because the time when politicians and policymakers make policy alone is long past," Mrs. Charette said, adding that "academic institutions and multilateral organisations can and should play a role in addressing the headwinds facing the rules-based order."

Despite the volatility we see across much of the world, the Canada-U.K. partnership remains solid. The recent Trudeau-May bilateral meeting built momentum for collaboration on security, climate change, gender equality and innovation. But governmental collaboration and trade agreements can only take us so far. It is ultimately up to the people, businesses and organizations in Canada and the U.K. to create the economic, academic and social ties that will assure our future prosperity and security in these tumultuous times. The Shoulder to Shoulder conference will continue to act as a means for seizing opportunities for collaboration and ensuring Canada-U.K. relations go from strength to strength. 


\section{About the Author}

Zak Biggs is a Research Coordinator with the International Policy and Trade Research Division (IPT) at The School of Public Policy. Zak's research interests include international trade and policy responses to labour market disruption. He sits on the planning committee of several of The School's international conferences including Atlantik-Bruecke, Shoulder to Shoulder and the North American Process. Zak holds a Masters of Public Policy from the University of Calgary and a Bachelor of Arts with Honours in Political Science from Carleton University.

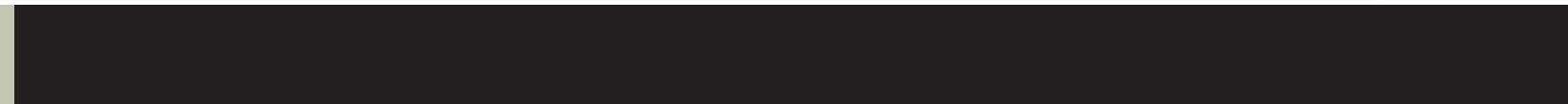




\title{
ABOUT THE SCHOOL OF PUBLIC POLICY
}

The School of Public Policy has become the flagship school of its kind in Canada by providing a practical, global and focused perspective on public policy analysis and practice in areas of energy and environmental policy, international policy and economic and social policy that is unique in Canada.

The mission of The School of Public Policy is to strengthen Canada's public service, institutions and economic performance for the betterment of our families, communities and country. We do this by:

- Building capacity in Government through the formal training of public servants in degree and non-degree programs, giving the people charged with making public policy work for Canada the hands-on expertise to represent our vital interests both here and abroad;

- Improving Public Policy Discourse outside Government through executive and strategic assessment programs, building a stronger understanding of what makes public policy work for those outside of the public sector and helps everyday Canadians make informed decisions on the politics that will shape their futures;

- Providing a Global Perspective on Public Policy Research through international collaborations, education, and community outreach programs, bringing global best practices to bear on Canadian public policy, resulting in decisions that benefit all people for the long term, not a few people for the short term.

The School of Public Policy relies on industry experts and practitioners, as well as academics, to conduct research in their areas of expertise. Using experts and practitioners is what makes our research especially relevant and applicable. Authors may produce research in an area which they have a personal or professional stake. That is why The School subjects all Research Papers to a double anonymous peer review. Then, once reviewers comments have been reflected, the work is reviewed again by one of our Scientific Directors to ensure the accuracy and validity of analysis and data.

\author{
The School of Public Policy \\ University of Calgary, Downtown Campus \\ 906 8th Avenue S.W., 5th Floor \\ Calgary, Alberta T2P $1 \mathrm{H} 9$ \\ Phone: 4032103802
}

\section{DISTRIBUTION}

Our publications are available online at www.policyschool.ca.

\section{DISCLAIMER}

The opinions expressed in these publications are the authors' alone and therefore do not necessarily reflect the opinions of the supporters, staff, or boards of The School of Public Policy.

\section{COPYRIGHT}

Copyright (c) Biggs 2019. This is an open-access paper distributed under the terms of the Creative Commons license CC BY-NC 4.0, which allows non-commercial sharing and redistribution so long as the original author and publisher are credited.

\section{ISSN}

ISSN 2560-8312 The School of Public Policy Publications (Print) ISSN 2560-8320 The School of Public Policy Publications (Online)

\section{DATE OF ISSUE}

March 2019

\section{MEDIA INQUIRIES AND INFORMATION}

For media inquiries, please contact Morten Paulsen at 403-220-2540. Our web site, www.policyschool.ca, contains more information about The School's events, publications, and staff.

\section{DEVELOPMENT}

For information about contributing to The School of Public Policy, please contact Sharon deBoer-Fyie by telephone at 403-220-4624 or by e-mail at sharon.deboerfyie@ucalgary.ca. 


\section{RECENT PUBLICATIONS BY THE SCHOOL OF PUBLIC POLICY}

ENERGY AND ENVIRONMENTAL POLICY TRENDS: CARBON TAX COSTS VARY WIDELY ACROSS HOUSEHOLDS https://www.policyschool.ca/wp-content/uploads/2019/03/Carbon-Tax-Costs-SPP-EE-Trends-MARCH-2019-final.pdf Trevor Tombe and Jennifer Winter | March 2019

\section{SOCIAL POLICY TRENDS: RENTS, SOCIAL ASSISTANCE AND THE SMALL TOWN ADVANTAGE}

https://www.policyschool.ca/wp-content/uploads/2019/02/Social-Policy-Trends-CMA-Rents-to-SA-February-2019.pdf Margarita Wilkins | February 2019

\section{THE GREENHOUSE GAS EMISSIONS COVERAGE OF CARBON PRICING INSTRUMENTS FOR CANADIAN PROVINCES} https://www.policyschool.ca/wp-content/uploads/2019/02/Carbon-Pricing-Dobson-Winter-Boyd-final.pdf Sarah Dobson, Jennifer Winter and Brendan Boyd I February 2019

\section{SHOULD ALBERTA ADOPT A LAND TRANSFER TAX?}

https://www.policyschool.ca/wp-content/uploads/2019/02/Land-Transfer-Tax-Dahlby-Larson.pdf Bev Dahlby and Braeden Larson | February 2019

\section{COMMUNITY REVITALIZATION LEVY AS A MUNICIPAL FINANCING MECHANISM IN ALBERTA}

https://www.policyschool.ca/wp-content/uploads/2019/02/Community-Revitalization-Spahlinger-Wanye.pdf Marina Spahlinger and Nancy Wanye | February 2019

MEASURING AND RESPONDING TO INCOME POVERTY

https://www.policyschool.ca/wp-content/uploads/2019/02/Income-Poverty-Kneebone-Wilkins.pdf Ronald Kneebone and Margarita Wilkins | February 2019

TAX POLICY TRENDS: CANADIAN POLICY MAKERS RESPOND TO U.S. TAX OVERHAUL https://www.policyschool.ca/wp-content/uploads/2019/02/TPT-Feb_Response-to-US-Tax-Overhaul_Final.pdf Philip Bazel and Jack Mintz | February 2019

URBAN POLICY TRENDS: WHERE SHOULD THE CITY OF CALGARY SPEND ITS MONEY?

https://www.policyschool.ca/wp-content/uploads/2019/02/UPT-Feb.-5-City-of-Calgary-Lucas.pdf Jack Lucas | February 2019

URBAN POLICY TRENDS: WHAT DO CALGARIANS THINK OF THEIR LOCAL, PROVINCIAL, AND NATIONAL ECONOMIES? https://www.policyschool.ca/wp-content/uploads/2019/01/Economic-Perceptions-SPP-Trends-Jan-2019.pdf Jack Lucas and Trevor Tombe | January 2019

SOCIAL POLICY TRENDS: GLOBAL REFUGEE RESETTLEMENT AND CANADA

https://www.policyschool.ca/wp-content/uploads/2019/01/Social-Policy-Trends-Refugee-Resettlement.pdf Robert Falconer | January 2019

URBAN POLICY TRENDS: THE POLICY PRIORITIES OF THE CALGARY BUSINESS COMMUNITY

https://www.policyschool.ca/wp-content/uploads/2019/01/SPP-Urban-Policy-TrendsBIZ-community.pdf Jack Lucas | January 2019

IMPROVING CANADA'S SELECTION OF ECONOMIC IMMIGRANTS

https://www.policyschool.ca/wp-content/uploads/2019/01/Economic-Immigrants-Vineberg-final.pdf Robert Vineberg | January 2019

URBAN POLICY TRENDS: MAYOR AND COUNCIL SATISFACTION IN CALGARY

https://www.policyschool.ca/wp-content/uploads/2019/01/Urban-Policy-Trends-Mayor-Council-Satisfaction-Lucas.pdf Jack Lucas | January 2019 